\title{
A Descriptive Study to Assess the Level of Knowledge Regarding the First Aid Management among School Teachers in Selected Schools of District Mohali, Punjab
}

\author{
Navjot Kaur*, Savitri and Mandeep Kaur \\ Chitkara School of Health Sciences, Chitkara University, Punjab, India
}

\begin{abstract}
Every parents of a child knows that it is hard enough to keep their child safe at home but when child goes off to school there is whole new set up of challenges. Parents totally entrust their children to the schools. They rely on the teachers as the second parents in the institute for learning. They know for the fact that their educators will want no harm to come their way. While they are busy working, they fully believe that their children are well cared for. On the other hand teachers have the responsibility to keep an eye on the students. They should make sure that they are comfortable and secured within the four walls of the school. So much more, the school staff has to be equipped with the knowledge of first aid.
\end{abstract}

Keeping this in mind a study was conducted among government school teachers regarding First Aid Management. The results of the study showed that most of the teachers (77.5\%) were having average knowledge regarding First Aid Management and $12.5 \%$ were having good knowledge and $10 \%$ were having poor knowledge.

\section{Keywords: Child safe; First aid; Illness; Mental development}

\section{Introduction}

First aid is the assistance given to any person suffering a sudden illness or injury with care provided to preserve life, prevent the condition from worsening, and/or promote recovery. It includes initial intervention in a serious condition prior to professional medical help being available, such as performing CPR while awaiting an ambulance as well as the complete treatment of minor conditions, such as applying a plaster to a cut. First aid is generally performed by the layperson with many people trained in providing basic levels of first aid, and others willing to do so from acquired knowledge. Mental first aid is an extension of the concept of first aid to cover mental health.

According to national first aid science advisory board, first aid should be learned by every person for this it is necessary that first aid training and education should be provided to everyone and should be important $\mathrm{t}$. In childhood school life plays an important role for everyone. It has a great or direct impact on children's physical and mental development. As the children come under the vulnerable group they are more important to get injuries and accidents especially when they are in school going age because at that time they are still maturing physically and mentally. In school teachers are the first caregivers who protect the children from trauma and accidents. Every teacher should have the ability to deal with any health emergency condition, when a children need healthcare. The victim should get immediate management of any accidents or trauma for good and early prognosis [1-3].

\section{Need of the study}

It is very difficult for a man to go out somewhere and return safely because we cannot give any guarantee or security to our life. This is the world of accidental world. So many accidents occur in many places like in schools, during travelling, when doing our daily activities and place is left out. People motive is just to get away from the place when accident occurs. They do not come forward to help or to have some first aid care because they are not aware of giving first aid for injuries. We could see the same situations in the school also. A lot of care must be taken while the students are in the schools playground or in public places. So they must have awareness on first aid and that has to be given for the school teachers. Because, first aid training not only provide with knowledge and skills to give life but also help to develop safety awareness and habits that promote safety at home, at work, during recreation and on the streets and highways.

Every time a health worker would not be available in the school: where the accidents can take place at any point of time. It is needed or desired that the staff of the school should have knowledge so that they can responsible to look after the minor ailments or accidents in the school. Student's safety is a major concern for the parents and the school staff [4].

\section{Problem statement}

It is a descriptive study to assess the level of knowledge regarding the First Aid Management among school teachers in selected schools of District Mohali, Punjab.

\section{Objectives}

1. To assess the knowledge of school teachers regarding the First Aid Management.

2. To find out the association between knowledge scores of teachers regarding First Aid Management with socio demographic variables [5].

3. To prepare information booklet based on First Aid Management for school teachers.

*Corresponding author: Navjot Kaur, Chitkara School of Health Sciences, Chitkara University, Punjab, India, Tel: 9316118538; E-mail: navjotrathore11@gmail.com

Received September 20, 2017; Accepted September 25, 2017; Published September 29, 2017

Citation: Kaur N, Savitri, Kaur M (2017) A Descriptive Study to Assess the Leve of Knowledge Regarding the First Aid Management among School Teachers in Selected Schools of District Mohali, Punjab. J Health Med Informat 8: 288. doi: 10.4172/2157-7420.1000288

Copyright: ( $) 2017$ Kaur N, et al. This is an open-access article distributed under the terms of the Creative Commons Attribution License, which permits unrestricted use, distribution, and reproduction in any medium, provided the original author and source are credited. 
Citation: Kaur N, Savitri, Kaur M (2017) A Descriptive Study to Assess the Level of Knowledge Regarding the First Aid Management among School Teachers in Selected Schools of District Mohali, Punjab. J Health Med Informat 8: 288. doi: 10.4172/2157-7420.1000288

Page 2 of 4

\section{Literature review}

Rakhi et al. conducted a research study titled "First aid knowledge among health assigned teachers of primary schools". They conducted a non-experimental survey. 40 samples from different schools were taken through purposive sampling technique. It was found that $72.5 \%$ had average knowledge and $25 \%$ have good knowledge and $2.5 \%$ have poor knowledge. Majority of teachers were female (52.5\%) from private schools and majority of educational status was post graduate 67.5\%. The study results revealed that there was significant association $(\mathrm{P}>0.05)$ of teachers qualification with the level of knowledge of First Aid Management and there was no significant association of knowledge with socio demographic i.e. gender, level of school and years of experience [6].

Awad et al. conducted a cross sectional descriptive study to explore primary school teachers knowledge regarding first aid [7]. Selfadministered questionnaire was used to assess the knowledge which included the socio demographic data and knowledge about first aid measures of most common incidence that occurs in schools. 187 teachers were included in the study their age were ranged between $25 \mathrm{yrs}$ and 58 yrs. $28.3 \%$ had attended a course on first aid. $52.4 \%$ had knowledge about bleeding, 31\% had knowledge about poisoning and $99.5 \%$ were aware of First Aid Management.

Joseph conducted study on awareness, attitude and practices of first aid among school teachers in Mangalore, South India. In their cross sectional study they included 146 teachers, self-administered questionnaires were used. Results of the study revealed that $47 \%$ teachers had received first aid training previously, $13 \%$ had poor knowledge and $87 \%$ had moderate knowledge of first aid. There were only eight teachers who were aware of correct cardiopulmonary resuscitation procedure. Among of the teachers 96 were willing to practice First Aid Management if training were provided to them [8].

\section{Methods}

In the present study Non-experimental Descriptive design was used. The population under the survey was assigned teachers working in Government school of District Mohali. Non-probability purposive sampling technique was used. 40 samples were selected for the study including both males and females [9].

\section{Results}

\section{Section 1: Description of frequency and percentage of demographic variables}

This section describes the characteristics of sample in terms of age, gender, marital status, educational status, occupation and income per month for the personal information. Frequency and percentage were computed for describing sample characteristics. These findings are illustrated in Table 1.

\section{Section 2: To find out the knowledge scores}

This section reveals the knowledge scores of the school teachers regarding the First Aid Management.

The Table 2 shows the criteria measures of the knowledge scores of the teachers. As the questionnaire was a set of 40 questions, we had made the measurement criteria as per the marks obtained by each teacher and it was divided into 3 categories as follows:
- Good: 21 to 29 questions were correct

- Average: 11 to 20 questions were correct

- Poor: 0 to 10 question were correct

The results obtained were as follows:

$12.5 \%$ had good knowledge whereas $77.5 \%$ had the average knowledge and rest $10 \%$ had poor knowledge regarding First Aid Management.

\section{Section 3: To find out the association between the knowledge scores and the sociodemographic variables}

This section deals with the findings related to the association between score and selected demographic variables. The Chi-square test was used to determine the association between the score levels and selected demographic variables.

Table 3 shows that the association between the level of scores and socio demographic variable, based on the 3rd objective. Chi-square test was used to associate the level of knowledge scores and selected demographic variables. There is no significance association between the level of scores and other demographic variables. The calculated Chi-square values were less than the table value at the 0.05 level of significance.

\begin{tabular}{|c|c|c|c|}
\hline Variables & Opts & Frequency (f) & Percentage (\%) \\
\hline \multirow{4}{*}{ Age (in years) } & $20-30$ & 6 & 15 \\
\hline & $31-40$ & 18 & 45 \\
\hline & $41-50$ & 11 & 28 \\
\hline & $51-60$ & 5 & 13 \\
\hline \multirow{2}{*}{ Gender } & Male & 8 & 20 \\
\hline & Female & 32 & 80 \\
\hline \multirow{4}{*}{ Education } & Graduate & 2 & 5 \\
\hline & Post graduate & 34 & 85 \\
\hline & Doctorate & 2 & 5 \\
\hline & Others & 2 & 5 \\
\hline \multirow{3}{*}{ Habitat } & Urban & 4 & 10 \\
\hline & Semi-urban & 32 & 80 \\
\hline & Rural & 4 & 10 \\
\hline \multirow{4}{*}{ Income } & Below Rs.10,000 & 4 & 10 \\
\hline & Rs. $10,001-20,000$ & 0 & 0 \\
\hline & Rs. $20,001-30,000$ & 3 & 8 \\
\hline & Above Rs. 30,000 & 33 & 83 \\
\hline \multirow{2}{*}{ Marital status } & Married & 39 & 98 \\
\hline & Unmarried & 1 & 3 \\
\hline \multirow{4}{*}{ Religion } & Sikh & 21 & 53 \\
\hline & Hindu & 19 & 48 \\
\hline & Muslim & 0 & 0 \\
\hline & Others & 0 & 0 \\
\hline \multirow{2}{*}{$\begin{array}{l}\text { Ever given First Aid } \\
\text { Management }\end{array}$} & Yes & 19 & 48 \\
\hline & No & 21 & 53 \\
\hline
\end{tabular}

Table 1: Reveals that most of the teachers were from the age group of between 31 $\mathrm{yrs}$ to $40 \mathrm{yrs}$ of age and the least ones were from the age group of $51 \mathrm{yrs}$ to $60 \mathrm{yrs}$ of age. Most of the teachers who participated in the study were females $80 \%$ whereas males where only $20 \%$. Most of the teachers were postgraduate $85 \%$ whereas only $5 \%$ of them were Doctorate. Most of the teachers where residing in semi-urban area and the other $20 \%$ were in urban and rural area. $83 \%$ of the teachers had the income of above $30,000,10 \%$ had below 10,000 and the others were in between. Most of the teachers were married (98\%) and the rest $2 \%$ were unmarried. $53 \%$ of the teachers belonged to Sikh religion and $48 \%$ belonged to Hindu religion. 
Citation: Kaur N, Savitri, Kaur M (2017) A Descriptive Study to Assess the Level of Knowledge Regarding the First Aid Management among School Teachers in Selected Schools of District Mohali, Punjab. J Health Med Informat 8: 288. doi: 10.4172/2157-7420.1000288

Page 3 of 4

\section{Discussion}

Non-experimental Descriptive Survey i.e.; research survey design was undertaken to assess the knowledge among health assigned teachers in selected schools of Dehradun city, Uttarakhand, from 16 may 2016 to 21 may 2016. The data was collected using socio demographic questionnaires and structured knowledge questionnaire from 40 study subjects selected by purposive sampling technique to assess their knowledge on first aid. The data collected was analyzed by using inferential statistics.

\section{Association between demographic variables and knowledge based data}

The present study shows no significant association between socio demographic variables i.e. gender, age, educational status, marital status, income, residential area etc.

\section{Knowledge scores of school teachers regarding first aid}

Findings shows the majority of health assign teachers were having average knowledge regarding first aid i.e.; 31 (77.5\%) and $5(12.5 \%)$ were having good knowledge and $4(10 \%)$ were having poor knowledge regarding first aid. This study was supported by following literatures.

\begin{tabular}{|c|c|c|}
\hline \multicolumn{3}{|c|}{ Criteria measure of knowledge score } \\
\hline Level of scores $\mathbf{N = 4 0}$ & Percentage & Frequency \\
\hline Good.(21-29) & 12.5 & 5 \\
\hline Average.(11-20) & 77.5 & 31 \\
\hline Poor.(0-10) & 10.0 & 4 \\
\hline \multicolumn{2}{|c|}{ Maximum=29; Minimum $=0$} \\
\hline
\end{tabular}

Table 2: The criteria measures of the knowledge score of the teachers.
According to a cross sectional analytical study conducted by Sonmer et al. In the study, a total number of 110 teacher's knowledge was assessed using questionnaire and a 20 point scale. The results showed a mean score of $11.9 \pm 2.9$. The study also reported that there was no major difference in knowledge level of teachers who received training previously to those who didn't receive training.

\section{Conclusion}

The present study was carried out among the teachers of government school regarding the knowledge on First Aid Management in school teachers. A total number of 40 teachers were taken for the study. The analysis of the data was done using the frequency test and Chi-square test in SPSS.

A non-experimental study was carried using purposive sampling technique, 40 samples of Government school teachers were taken. Results shows that majority of the teachers were having average knowledge about the first aid i.e. $12.5 \%$ has good scores, $77.5 \%$ has average and $10 \%$ has poor scores.

Most of the participants in the study were females (married) of the age group between 31 yrs to 40 yrs residing mostly in semi urban areas with a post graduate degree with the income of above 30,000 rupees.

\section{Nursing Implication}

The findings of the study are implicated in different areas such as:

- Nursing practice

- Nursing education

- Nursing administration

\begin{tabular}{|c|c|c|c|c|c|c|c|c|c|}
\hline \multicolumn{2}{|c|}{ Demographic data } & \multicolumn{3}{|c|}{ Levels $(\mathrm{N}=\mathbf{4 0})$} & \multicolumn{5}{|c|}{ Association with knowledge score } \\
\hline Variables & Opts & Good & Average & Poor & Chi-test & P-value & df & Table value & Result \\
\hline \multirow{4}{*}{ Age (in years) } & $20-30$ & 4 & 2 & 0 & \multirow{4}{*}{2.835} & \multirow{4}{*}{0.829} & \multirow{4}{*}{6} & \multirow{4}{*}{12.592} & \multirow{4}{*}{ Not significan } \\
\hline & $31-40$ & 9 & 7 & 2 & & & & & \\
\hline & $41-50$ & 7 & 4 & 0 & & & & & \\
\hline & $51-60$ & 3 & 2 & 0 & & & & & \\
\hline \multirow{2}{*}{ Gender } & Male & 3 & 5 & 0 & \multirow{2}{*}{2.862} & \multirow{2}{*}{0.239} & \multirow{2}{*}{2} & \multirow{2}{*}{5.991} & \multirow{2}{*}{ Not significan } \\
\hline & Female & 20 & 10 & 2 & & & & & \\
\hline \multirow{4}{*}{ Education } & Graduate & 0 & 2 & 0 & \multirow{4}{*}{6.363} & \multirow{4}{*}{0.384} & \multirow{4}{*}{6} & \multirow{4}{*}{12.592} & \multirow{4}{*}{ Not significan } \\
\hline & Post graduate & 19 & 13 & 2 & & & & & \\
\hline & Doctorate & 2 & 0 & 0 & & & & & \\
\hline & Others & 2 & 0 & 0 & & & & & \\
\hline \multirow{3}{*}{ Habitat } & Urban & 1 & 2 & 1 & \multirow{3}{*}{4.926} & \multirow{3}{*}{0.295} & \multirow{3}{*}{4} & \multirow{3}{*}{9.488} & \multirow{3}{*}{ Not significan } \\
\hline & Semi-urban & 19 & 12 & 1 & & & & & \\
\hline & Rural & 3 & 1 & 0 & & & & & \\
\hline \multirow{4}{*}{ Income } & Below Rs. 10,000 & 3 & 1 & 0 & \multirow{4}{*}{1.801} & \multirow{4}{*}{0.772} & \multirow{4}{*}{4} & & \\
\hline & Rs. $10,001-20,000$ & 0 & 0 & 0 & & & & 9488 & Not cianificant \\
\hline & Rs. $20,001-30,000$ & 1 & 2 & 0 & & & & 9.400 & INot sigmintidat \\
\hline & Above Rs. 30,000 & 19 & 12 & 2 & & & & & \\
\hline Morital statur & Married & 22 & 15 & 2 & 0750 & 0685 & 2 & 5001 & Nlat cianificont \\
\hline IMrarıal status & Unmarried & 1 & 0 & 0 & 0.158 & 0.685 & 2 & 5.991 & Not sıgnitıcant \\
\hline & Sikh & 15 & 5 & 1 & & & & & \\
\hline Religinn & Hindu & 8 & 10 & 1 & 3706 & 0157 & 2 & 5.991 & Not significant \\
\hline Nengivit & Muslim & 0 & 0 & 0 & & & 2 & 0.991 & \\
\hline & Others & 0 & 0 & 0 & & & & & \\
\hline Ever given First Aid & Yes & 11 & 7 & 1 & (10 & 0905 & 2 & 5001 & Nlat cianificant \\
\hline Management & No & 12 & 8 & 1 & 0.010 & 0.995 & 2 & 5.991 & Not Signiticant \\
\hline
\end{tabular}

Table 3: Association between the level of scores and sociodemographic variable. 
Citation: Kaur N, Savitri, Kaur M (2017) A Descriptive Study to Assess the Level of Knowledge Regarding the First Aid Management among School Teachers in Selected Schools of District Mohali, Punjab. J Health Med Informat 8: 288. doi: 10.4172/2157-7420.1000288

- Nursing research.

\section{Nursing practice}

- Education and training can be provided to the teachers in school by nurses.

- Improving the skills through attending varies training program me.

\section{Nursing education}

- Nurses can provide the orientation to the school teachers about the CPR and various other common problems for example seizures, fainting etc.

- Booklet can be given regarding basic first aid guidelines.

\section{Nursing administration}

- The authorities should allow nurses to conduct mock drills to teach teachers regarding First Aid Management.

\section{Recommendations}

a) The study can be done in large population to generalize the findings.

b) Comparison between the government and private school teachers regarding the knowledge of First Aid Management can be done. c) Randomized sampling technique can be done in future study.

d) Experimental study can be done to assess the effectiveness of workshop regarding the knowledge through pretest and posttest.

\section{Limitations}

1. The study was conducted on small sized sample.

2. The present study is limited to assess the knowledge regarding first aid among teachers.

\section{References}

1. https://en.m.wikipedia.org/wiki/First_aid

2. http://www.medicalnewstoday.com/articles/153849.php

3. https://en.m.wikipedia.org/wiki/First_aid

4. https://www.gov.hk/en/residents/culture/recreation/activities/firstaid.htm

5. Yallayaswamy NN (1997) First aid and emergency nursing 1997: 1-10.

6. Rakhi P, Richa C, Sushant D, Dabral S, Nathani S, et al. (2015) First aid knowledge among health assigned teachers of primary schools. Int J Res Med Sci 5: 1522-1523.

7. Awad S, Samghan AL, Faithah H, Faisal M, Ahahfani AL (2015) Primary school teachers' knowledge about first aid. Med J Cairo Univ 83: 541-542.

8. Joseph N (2015) Awareness, attitude and practice of first aid among schoo teachers in Mangalore south India. J Prim Health Care 7: 274-275.

9. Masih S (2014) Knowledge and Practice of primary school teachers about first aid management of selected minor injuries among children. Int J Med Pub Health 4: 458-459. 